\title{
The Social Repertoire of Sulawesi Macaques
}

\author{
B. Thierry ${ }^{1)}$ - E.L. Bynum ${ }^{2)}$ - S. Baker ${ }^{3)}$ - M.F. Kinnaird ${ }^{4)}$-S. Matsumura ${ }^{5)}$ \\ Y. Muroyama $^{5)} \cdot$ T.G. O'Brien ${ }^{4)} \cdot$ O. Petit $^{1)} \cdot$ K. Watanabe ${ }^{5)}$ \\ 1) CNRS, Université Louis Pasteur, Strasbourg, France \\ 2) Organization for Tropical Studies, Durham, USA \\ 3) Department of Psychology, James Madison University, Harrisonburg, USA \\ 4) Wildlife Conservation Society, Bronx, USA \\ 5) Primate Research Institute, Kyoto University, Inuyama, Japan
}

\begin{abstract}
The social repertoire of Sulawesi macaques is presented, based upon data recorded both in the wild and from captive populations. The repertoire describes behaviors observed in social contexts, including communication patterns, movement patterns, sexual patterns, infant-related and play behaviors, and triadic interactions. Most of these behavior patterns are shared by all known Sulawesi taxa. The form or function of certain patterns depart significantly from what has been reported in other macaques, while particular similarities may be linked to phylogenetic relationships within the genus Macaca.
\end{abstract}

\section{INTRODUCTION}

Much of the scientific endeavor consists in testing hypotheses and theories. However, the study of animal behavior is usually based in behavioral units which are qualitatively recognized, more or less arbitrarily defined, and not attached to explicit hypotheses. The subjective nature of behavioral units makes the establishment of the behavioral repertoire of species a neglected task. Description of behavior is usually considered a preliminary research task rather than an end in of itself. However, knowledge of basic patterns is as necessary to the study of behavior as detailed descriptions of forms are to anatomy. Ethograms must be viewed as tentative inventories to which additions and refinements should be continuously brought, with every advance diminishing the extent of subjectivity in our accounts (Coehlo \& Bramblett, 1989). The present paper presents such a behavioral inventory for Sulawesi macaques. It should be considered both a tool and an end result.

Several macaque taxa live on the island of Sulawesi in Indonesia. They belong to the silenus-sylvanus lineage, one of the three phyletic radiations recognized in the genus Macaca (Fooden, 1976; Delson, 1980; Hoelzer \& Melnick, 1996). This lineage includes the Barbary macaque (M. sylvanus), the lion-tailed macaque (M. silenus), the pig-tailed macaque (M. nemestrina) and the Sulawesi macaques. Sulawesi taxa share many morphological, physiological, and molecular features, and are probably derived from a single ancestral population (Fooden, 1969; Fooden \& Lanyon, 1989; Kawamoto, 1996; Evans et al., 1999). Currently, 
secondary intergradation is evidenced by the hybridization occurring on the border areas between taxa ranges (Albrecht, 1978; Groves, 1980; Camperio Ciani et al., 1989; Watanabe \& Matsumura, 1991; Watanabe et al., 1991; Froehlich \& Supriatna, 1996; Bynum et al., 1997). The evolutionary diversification of Sulawesi taxa possibly originated from the temporary isolation of different parts of the island in geological time (Fooden, 1969; Bynum et a1., 1997). Sulawesi taxa are variously classified as four (Groves, 1980) or seven species (Fooden, 1969). We provisionally retain Fooden's nomenclature, which distinguishes the following species: crested macaque (M. nigra), Gorontalo macaque (M. nigrescens), Heck's macaque (M. hecki), Tonkean macaque ( $\boldsymbol{M}$. tonkeana), moor macaque ( $\boldsymbol{M}$. maurus), booted macaque ( $\boldsymbol{M}$. ochreata), and Muna-Buton macaque ( $M$. brunnescens). These seven taxa are generally allopatrically distributed over the island (Fig. 1), and may be found in both lowland and lower montane forests (Whitten et al, 1987; Supriatna et al., 1992).

The ethograms of the Sulawesi macaque taxa remain incomplete. Of the taxa, $\boldsymbol{M}$. tonkeana and $\boldsymbol{M}$. nigra are the best known, with a description of the main patterns of communication available for each (Dixson, 1977; Nickelson \& Lockard, 1978; Thierry, 1984; Masataka \& Thierry, 1993). However, the lack of standardization in the definition of behaviors and the absence of data for most other taxa have made it difficult to recognize differences, similarities, and / or homologies among the members of the lineage. In this paper, we compile information from the research teams involved in the study of the ecology, behavior and social organization of Sulawesi macaques with the aim of providing a standard applicable to every taxon from the island. This should improve communication between observers working in different places, provide a baseline for future studies, and facilitate comparisons among Sulawesi taxa and with other macaque species for which the social repertoire has been established (Hinde \& Rowell, 1962; Kaufman \& Rosenblum, 1966; Bertrand, 1969; Deag, 1974; de Waal et al., 1976; Hohmann \& Herzog, 1985; Johnson, 1985; Palombit, 1993).

\section{SUBJECTS AND SAMPLING}

The repertoire is based upon previously published studies supplemented by unpublished data from the present authors. Table 1 summarizes information about the conditions of each study: location of captive and wild populations studied, number of individuals and groups sampled, number of observation hours, and personnel. The table does not include early reports based on occasional observations (Darwin, 1872; van Hooff, 1967; Lindsay, 1976; Groves, 1980; Bismark, 1982).

With regard to the homology of behavior patterns across populations and taxa, it is worth adding that several authors have experience working with three or four Sulawesi taxa (S. Baker, E. Bynum, O. Petit) or all of them (K. Watanabe). For cross-checking, further observations were made by $\mathbf{B}$. Thierry in various

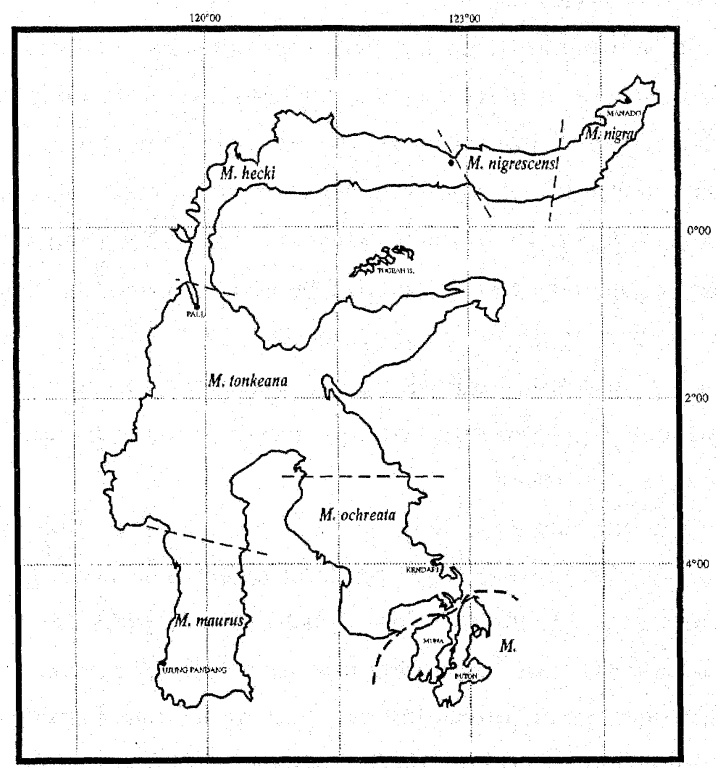

Fig. 1. Ranges of Sulawesi macaques. Based on Fooden (1969) and Bynum et al. (1997). 
groups both in the wild and in zoological parks; several hours of observation were completed in each of the following places: Zürich, Singapore, Jakarta Zoos and Tangkoko-DuaSudara Nature Reserve for M. nigra; Ozoir-la-Ferrière Zoo (Paris) and Karaenta Nature Reserve for M. maurus; Jakarta Zoo for $\boldsymbol{M}$. hecki; and different sites in Central Sulawesi for $M$. tonkeana. These observations allowed to recognize that behavior patterns were homologous among the various populations observed.

\section{SOCIAL REPERTOIRE}

The repertoire is presented in narrative form. It describes behaviors observed in social contexts, including movement patterns, communication patterns, sexual patterns, play and infant-related behaviors, solitary actions deemed likely to be involved in social interactions, and triadic interactions. No spectrograms are available for most Sulawesi macaque vocalizations, with the exception of male loud calls (Muroyama \& Thierry, 1998). Therefore, descriptions of vocalizations are made with reference to spectrograms provided by Masataka and Thierry (1993) for M. tonkeana.

For each behavior, the form of the behavior pattern, its main contexts of occurrence and likely function are described. The taxa for which the pattern is known are then mentioned. Taxa are abbreviated as follows: B, M. brunnescens; H, M. hecki; M, M. maurus; E, M. nigrescens; N, M. nigra; O, M. ochreata; T, M. tonkeana. Hybrids: $\mathrm{B} / \mathrm{O}, M$. brunnescens $x M$. ochreata $\mathrm{H} / \mathrm{T}, M$. hecki $x$ M. tonkeana. Unless explicitly indicated, the absence of a report of a behavior for a particular taxon should not be taken as evidence that the pattern does not occur.

Published bibliographical sources and alternate names are given in brackets. In some cases, the bibliographical sources represents the original description of the behavior pattern, while in others, simply a report of the pattern in a taxon.

Actions and expressions are numbered individually from 1 to 128 . Play patterns and special triadic interactions are numbered from 129 to 149 , and may include previously described actions and expressions.

\section{Behavior Patterns}

1. Low coo. A brief and rather nasal sound of low frequency. This is a contact call exchanged by individuals at proximity. M, E, N, T, H/T (Masataka \& Thierry, 1993: A-2).

2. Clear coo. A brief and tonal sound with wide frequency modulation. This call is given when individuals are several to ten meters apart. M, E, N, T, H/T (Masataka \& Thierry, 1993: A-3).

3. Harsh coo. A brief sound combining tonal and harsh components. This call is emitted by individuals far or separated from each other. M, E, N, T, H/T (Masataka \& Thierry, 1993: A-4).

4. Warning call. A brief sound composed by a tonal unit followed by a harsh unit. Sometimes, the harsh unit is predominant. The call sounds like a bark. It is uttered when individuals discover something unusual, or in the presence of predators. While repeated calls induce flight by listeners, the utterance of a few calls may attract them toward the vocalizer. E, N, T (Masataka \& Thierry, 1993: B-1).

5. Affiliation call. A vocalization emitted as a phrase composed of repeated units ("ho-ho-ho"), each unit presenting a wide frequency modulation. The call occurs in intense affiliative interactions (e.g., around mothers carrying infants), is loud in volume and often associated with clasps, approaches and expressive runs. M, N, T, B /O (Thierry, 1984: staccato vocalization; Masataka \& Thierry, 1993: 4-5).

6. Estrous call. A call emitted as a phrase composed of repeated units ("ro-ro-ro"). The units consist of a 


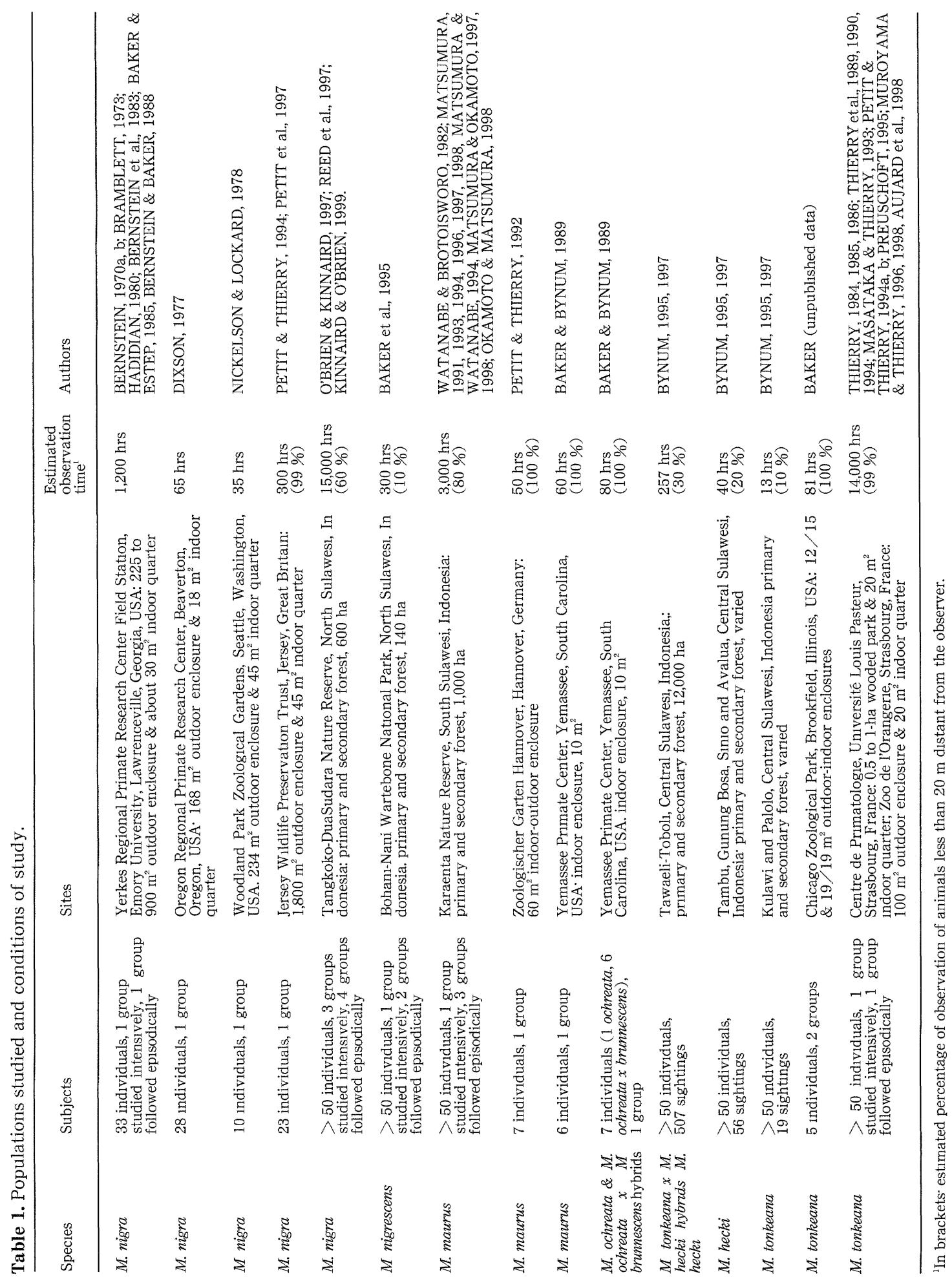


narrow noise beam and an additional higher frequency band. The call is emitted by estrous females presenting sexual morphological changes. In $M$. tonkeana, calls uttered outside the context of mating are generally longer and louder than those induced by copulation. In $M$. nigra, such calls have been heard only in copulating females. These calls were not heard in $M$. maurus and $M$. nigrescens. N, T (Masataka \& Thierry, 1993: C-1; Aujard et al., 1998).

7. Copulation call. A squeak ("ee") resembling the rattle. It is accompanied by the copulation open mouth display. It is sometimes emitted by the male during mating. M, N, T (Dixson, 1977: hoarse bark; Masataka \& Thierry, 1993; Aujard et al., 1998).

8. Soft grunt. A grunting sound, often emitted in series, and uttered in affiliative interactions and contacts. M, N, T (Thierry, 1984; Matsumura, 1991, 1994, 1997; Petit \& Thierry, 1992, 1994a; Masataka \& Thierry, 1993: D-1; Matsumura \& Okamoto, 1998: affiliative grunt).

9. Whimpering grunt. A soft grunt with a nasal component, generally emitted by immatures after taking refuge next to an older individual following rough handling or aggression. It may occur in affiliative contacts between adults. N, T.

10. Panting grunt. A staccato breathing emitted during play. T (Thierry et al., 1989; Preuschoft, 1995: voiced breathing).

11. Hard grunt. A plosive grunt containing narrow noise beams. It is accompanied by staring and sometimes jaw movement. It is emitted by individuals as a threat given at distance before attack or toward strangers. M, N, T (Thierry, 1984: snarl; Masataka \& Thierry, 1993: D-2; Muroyama \& Thierry, 1998).

12. Pant-bark. A mono- or biphasic sound emitted in phrases of several units, associated with staring, chase and aggression. M, T (Masataka \& Thierry, 1993: E-1).

13. Bark. A loud and brief vocalization that may be repeated, the mouth forming a $O$ shape. It is associated with staring, chase and aggression. H, M, N, T, B /O, H / T (Thierry, 1984; Masataka \& Thierry, 1993: E-2; Reed et al., 1997; Muroyama \& Thierry, 1998).

14. Rattle. A brief and sharp call, usually repeated. It is accompanied by the half-open mouth display. It acts as a mild threat aiming warning the addressed individual to keep away or stop the attending action. M, N, T (sharp vocalization: Thierry, 1984; Masataka \& Thierry, 1993: E-3).

15. Chuckle. A sharp and tonal call, sometimes surperimposed by a noisy component, accompanied by the open mouth bared-teeth display. It acts as a threat and is uttered by individuals initiating an agonistic interaction. M, T (Masataka \& Thierry, 1993: E-5).

16. Gecker. A tonal sound with frequency modulation, often repeated, accompanied by the open mouth bared-teeth display. It is emitted as a protest in agonistic interactions. M, N, T (Masataka \& Thierry, 1993: E-6; Petit et al., 1997).

17. Tonal scream. A long shrill vocalization accompanied by the open mouth bared-teeth display. It is typically emitted by an individual in conflict with a stronger individual and seeking refuge near an ally, or may be uttered by an individual while avoiding another. M, N, T (Thierry, 1985: aggressive-like vocalization; Masataka \& Thierry, 1993: E-7).

18. Screech. A loud, shrill vocalization accompanied by the open mouth bared-teeth display, uttered during agonistic interactions, it corresponds to violent protest and attack by the performer. M, E, N, T (Masataka \& Thierry, 1993: E-8).

19. Noisy scream. A shrilling vocalization accompanied by the open mouth bared-teeth display. It is 
uttered in agonistic interactions and is associated with flight or crouch. M, E, N, T (Masataka \& Thierry, 1993: E-10).

20. Pulsed scream. A short, shrilling vocalization, accompanied by the open mouth bared-teeth display. It is uttered by infants in response to rejection, rough handling or aggression. It is associated with flight or crouch. M, N, T (Masataka \& Thierry, 1993: E-9).

21. Whistle. A loud tonal vocalization with frequency modulation, lasting several seconds. This is a "lost call, a coo emitted by isolated infants calling for the mother or an alloparent. M, E, T.

22. Twit. A brief, loud, tonal sound, characterized by an initial ascending frequency modulation forming one peak, followed by a descending frequency modulation. It is emitted by individuals from both sexes witnessing or participating in intense social interactions (e.g., polyadic conflicts or affiliative interactions like play or interactions around infants). The call has not been reported in M. nigra. M, T (Masataka \& Thierry, 1993: E-11; Muroyama \& Thierry, 1996).

23. Cackle. A brief call composed of two frequency modulated units (each sounding like a twit). It is emitted by males at least four year-old witnessing or participating in intense polyadic conflicts. In one instance, it was uttered by an infant male momentarily separated from its group; it emitted the call repeatedly until rescued by the mother. The cackle has not been reported in M. nigra. T (Masataka \& Thierry, 1993: E-4).

24. Loud call. A high-pitched vocalization emitted by adult males either in non-specific situations or in the context of arousal and social tension (e.g., social conflict, separation of mates from the main group, presence of a stranger). It is composed of phrases consisting of frequency-modulated units. Interspecific variation in structure and context of occurrence of loud calls is detailed in Table 2. B, H, M, E, N, O, T, H/T (Lindsay, 1976; Bramblett, 1973; Dixson, 1977; Watanabe \& Brotoisworo, 1982; Thierry et al., 1989, Matsumura, 1991; Masataka \& Thierry, 1993: A-1; Reed et al., 1997; Muroyama \& Thierry, 1998; Okamoto \& Matsumura, 1998; Kinnaird \& O’Brien, 1999).

25. Scalp retraction. The scalp is retracted, ears may be flattened against the head while the individual looks at a partner. This may be associated with physical approach. This is an invitation to play or engage in an affiliative interaction. M, E, N, T, H $/$ T (Hadidian, 1980: brow retraction; Preuschoft, 1995: scalp lifting).

26. Silent bared-teeth. The upper lip or both lips are vertically retracted, exposing the teeth and sometimes the gums. The corners of the mouth may be drawn back. The jaw may be either closed or opened to various degrees. The scalp is often raised and the ears flattened. This is an affiliative display, it is commonly observed during affiliative interactions and social play. It may be used to initiate a positive interaction and is frequently associated to an approach. In exceptional occasions, it may be seen in individuals retreating in response to a threat. In play, the lips may be more or less retracted; sometimes the subject opens the mouth to softly bites the other, the lips still being not retracted as in the relaxed open mouth display described in most nonSulawesi macaques. B, H, M, E, N, O, T, B /O, H/T (Darwin, 1872; van Hooff, 1967; Bernstein, 1970a: high grin, snarl?; Dixson, 1977: narrow grin, high grin, play face; Nickelson \& Lockard, 1978; Groves, 1980; Thierry, 1984, 1985, 1986; Thierry et al., 1989; Petit \& Thierry, 1992, 1994a; Matsumura, 1994; Baker et al., 1995; Preuschoft, 1995; Matsumura \& Okamoto, 1998).

27. Lipsmack. The lips are pursed and the lower jaw is moved up and down rapidly and rhythmically. The jaw may be thrust upward. The mouth may be slightly open with the tongue moving back and forth. The lips 
often produce an audible sound. Alternatively, the mouth may be closed, sometimes the teeth knock together. Eyelids are generally half-lowered. The scalp may be retracted and the ears flattened. The display is used during affiliative interaction. It may also end a conflict, and acts as an appeasement or reassurance signal. $\mathbf{H}$, M, E, N, O, T, B /O, H /T (Darwin, 1872; van Hooff, 1967; Bramblett, 1973; Lindsay, 1976; Dixson, 1977; Nickelson \& Lockard, 1978; Groves, 1980; Thierry, 1984, 1985, 1986; Bernstein \& Baker, 1988; Thierry et al., 1990; Matsumura, 1994, 1997; Petit \& Thierry, 1994a; Preuschoft, 1995; Reed et al., 1997, Matsumura \& Okamoto, 1998).

Note: There may be rapid alternation between silent bared-teeth and lipsmack. This acts as an affiliative or a submissive signal. This alternation does not seem to constitute a ritualized display. However, some authors (van Hooff, 1967; Dixson, 1977) see it as such in $M$. nigra and refers to it as teeth-chattering. This behavior was rarely observed in $M$. maurus and $M$. tonkeana. M, N, T.

28. Protruded lips. The lips are pursed, the lower one being tightly pressed against the upper one. The jaw is thrust upward and eyelids are half-lowered. The display is typically emitted at a distance. It often precedes mating and is then accompanied by turning face away from the partner. It may be associated with threatening behavior. In $M$. tonkeana, it might be an invitation to approach or to follow. Protruded lips displays were never observed in M. nigra and one M. ochreata. M, T (Thierry, 1984, 1985; Preuschoft, 1995).

29. Staring. A visual fixation on another individual. The scalp may be retracted or not. The head may be thrust forward. The performer is tense. This expression acts as a low-level threat aimed at warning or stopping the addressed individual. M, N, T (Thierry, 1984).

30. Half-open mouth. The mouth is slightly open with corners drawn back, the lower lip may be retracted and the teeth are partly visible. This display is accompanied by staring. It is occasionally silent but is most often accompanied by the rattle vocalization. This expresssion is associated with aggression and acts as a mild threat. M, E, N, T (Dixson, 1977: threat; Thierry, 1984; Preuschoft, 1995: forward bared-teeth).

31. Open mouth bared-teeth scream. The mouth is open wide with corners retracted, exposing the teeth and sometimes the gums. This facial expression is accompanied by staring and screaming vocalizations (screams, screeches, chuckles, geckers). The display occurs in agonistic contexts. Depending on the vocalization emitted, it may act as a threat or a protest, and may be associated with an attack or a counter-attack. M, E, N, T (Dixson, 1977: grimace; Nickelson \& Lockard, 1978: high submissive intensity grimace; Thierry, 1984).

32. Jaw movement. The head is thrust forward, and the lower jaw is moved up and down rapidly and rhythmically. The mouth is closed or slightly open and the lips slightly protrude. The teeth may be knocked together, and the scalp may be retracted and ears flattened. This expression is accompanied by staring, and may be silent or associated with the hard grunt. It is seen in individuals about to attack. This is a threat usually given at a distance. N, T (Bernstein, 1970a: aggressive lipsmacking; Dixson, 1977; Thierry, 1984; Bernstein \& Baker, 1988).

33. Silent bared-teeth jaw movement. The lips are vertically retracted, exposing the teeth, and the lower jaw is moved rhythmically and silently. The head is thrust forward. Adult males display this facial expression toward estrous females before approach, genital inspect or mount. This facial expression was never observed in $M$. maurus and M. tonkeana. $\mathbf{N}$.

34. Copulation open mouth. The corners of the mouth are drawn back, slightly exposing the teeth; the mouth is open in a half-moon form. This expression may be accompanied by the copulation call, and is displayed by the male during mating. M, E, N, O, T (low intensity submissive grimace: Nickelson \& Lockard, 
1978).

35. Close looking. An individual physically brings face to close range of another to establish visual contact. This behavior is typically performed after an approach or toward an infant clinging to the mother. $\mathrm{M}, \mathrm{E}, \mathrm{N}$, T, H /T, B /O (Baker \& Bynum, 1989: face; Bynum, 1995; Preuschoft, 1995: face-to-face).

36. Glance. A tense individual looks around it, making quick glances while avoiding eye contact with another individual which is interacting or attempting to interact. M, E, N, T (Dixson, 1977).

37. Looking away. An individual turns the face and thus the gaze, resulting in avoidance of eye contact with another individual which is interacting or attempting to interact. M, N, T (Nickelson \& Lockard, 1978).

38. Looking backward. An individual turns the head to look at an individual. This may be performed by an individual mounted or presenting toward the partner mounting or to be presented. When performed by a playing or locomoting individual, the pattern may induce play chasing or following in the partner. M, E, N, T (Dixson, 1977; Bernstein \& Baker, 1988).

39. Turning face away. In the course of an affiliative interaction, an individual breaks visual contact in briskly turning the head to one side, up or backward. The head is generally brought back in the direction of the partner. The pattern may be repeated. The performer's behavior is dynamic, usually associated with affiliative vocalizations, contacts and facial expressions. M, E, N, T, H/T (Thierry, 1984, 1985; Petit \& Thierry, 1992; head tossing: Preuschoft, 1995).

40. Expressive run. In the course of an affiliative interaction, an individual runs away for several meters. It often comes back and resumes the interaction. This behavior is associated with affiliative vocalizations, contacts and facial expressions. M, E, N, T (Thierry, 1984, 1985, 1986; Thierry et al., 1990; Petit \& Thierry, 1992; Matsumura, 1994).

41. Turning toward. An individual orients its body toward another without changing its location. This is followed by looking at and/or interacting with the partner. M, E, N, T.

42. Turning away. An individual orients its body away from a partner in response to its behavior. This deters access to the performer. $\mathbf{M}, \mathbf{E}, \mathbf{N}, \mathrm{T}$.

43. Contact deterrence. An individual pushes away a partner (often the hand) with its hand in response to another's behavior. A mother may prevent an infant from clinging by pushing or holding it away. When carrying an infant or an object, an individual may also interpose its hand or arm to prevent contact by the partner. M, N, T (Preuschoft, 1995).

44. Ignore. An individual does not respond to a threat, a presentation, a grooming solicitation, a play initiation or any other behavior addressed to it by another individual. M, E, N, T.

45. Approach. An individual moves toward a partner while glancing or looking at it. H, M, E, N, T, B $/ \mathrm{O}$, $\mathrm{H} / \mathrm{T}$.

46. Following. An individual walks or runs after a moving partner. M, E, N, T, H / T (Reed et al., 1997; Matsumura, 1998).

47. Invitation to follow. An individual moves in one direction, sometimes stopping and looking backward toward a partner. This may induce following by the partner, e.g. a consorting male, a play partner or a mother's infant. M, N, T.

48. Passing contact. An individual in motion contacts another with the body without stopping. The contact does not involve the mouth or the hands. $\mathrm{M}, \mathrm{E}, \mathrm{N}, \mathrm{T}, \mathrm{H} / \mathrm{T}$.

49. Bump. An individual in motion contacts another with the body and stops. This contact does not involve 
the mouth or the hands. M, N, T (Thierry, 1986: passive contact).

50. Mouth approach. An individual brings its mouth toward that of another, while looking or smelling. The mouth is closed, contact may occur. M, E, N, T (Nickelson \& Lockard, 1978: contact with the face; Thierry, 1984; Petit \& Thierry, 1994a: mouth to mouth; Matsumura, 1996).

51. Mouthing. An individual places its open mouth on the partner without closing it. This is an affiliative contact that may be directed toward an infant clinging to the mother, for instance. In rare instances, mouthing the penis of a male infant was observed. M, N, T, B/O (Thierry, 1984, 1986; Preuschoft, 1995; Matsumura, 1997).

52. Nibbling. An individual softly bites the body of the partner. This contact may occur in clasping, playing or be directed toward an infant. During mating, the male may occasionnally nibble the female's nape. Nibbling was observed only during social play in M. nigra. M, E, N, T (Nickelson \& Lockard, 1978: play-bite; Thierry, 1984: mouthing; Baker \& Estep, 1985; Petit \& Thierry, 1994b; Thierry et al., 1994; Preuschoft, 1995).

53. Licking. An individual briefly licks another. This contact may occur during social grooming or be directed toward an infant. M, N, O, T.

54. Suck inducing. An individual inserts its finger or tongue into the mouth of a young infant for sucking. T.

55. Pat. An individual gives a pat to another with the flat of the hand. This brief affiliative contact is usually directed toward infants. $\mathrm{N}, \mathrm{T}$.

56. Pressure. An individual softly pushes with the hand an individual not looking at it to attract its attention and initiate an affiliative interaction. $\mathrm{N}, \mathrm{T}$.

57. Touch. An individual contacts another lightly with hand in a region other than the hip. This affiliative contact does not involve pushing, grasping or pulling. M, E, N, T (Nickelson \& Lockard, 1978; Thierry, 1986; Matsumura, 1991, 1997).

58. Hip holding. An individual places the hand on or grasps the hip(s) of another. This behavior may be an initiation to mounting and often precedes it. M, E, N, O, T, H/T (Dixson, 1977; Thierry, 1984: grasping the hindquarters; Bynum, 1995).

59. Positioning. An individual pushes or grasps the pelvic region of a recipient to raise or orient it toward himself for anogenital inspection or mounting. M, E, N, T (Dixson, 1977; Aujard et al., 1998: solicitation).

60. Grasp. An individual gently grasps another with one or both hands. This contact does not include grasping the genitals or orienting the hindquarters. This is an affiliative contact, it may be sometimes used to retain a partner. M, N, T, H/T (Thierry, 1984; Matsumura, 1991; Petit \& Thierry, 1992).

61. Genitals grasp. A male gently grasps the scrotum or penis of another male. This is an affiliative contact often accompanied with lipsmack or silent bared-teeth displays. Grasping the scrotum or penis sometimes occurs in $M$. maurus and $M$. tonkeana. Grasping the penis is a frequent occurrence among males in $M$. nigra where it may be mutual. M, N, T (Thierry, 1984; Reed et al., 1997: penis grab).

62. Hug. An individual passes one or both hands, or one or both arms around the body of another in multiple combinations. There may be a simultaneous grasping of the fur. Ventro-ventral contact is excluded. This is an affiliative contact that may be accompanied by lipsmack. It may be used to retain a partner. In $\boldsymbol{M}$. maurus and $M$. tonkeana, a special form may occur: in hold bottom, an individual clasps the haunches of a partner with both hands and grasps its legs with feet as in a mount. M, N, T, H/T (Thierry, 1984: reaching 
around, hugging; Matsumura, 1991).

63. Ventral embrace. An individual encircles another ventro-ventrally with arms. There is contact between heads or chests. Embracing may be mutual or unilateral. There may be a simultaneous grasping of the fur. This is an affiliative contact that may be accompanied by lipsmack. M, E, N, T (Thierry, 1984; Bernstein \& Baker, 1988; Matsumura, 1991; Petit \& Thierry, 1992; 75).

64. Lateral embrace. Two females stand side by side but facing in opposite directions, each drapes an arm over the other's hips or waist, sometimes both partners inspect the other's genitals. This kind of embrace is possibly ritualized. It may be accompanied by lipsmack. With regard to $M$. tonkeana, this behavior was observed in females from both Brookfield Zoo groups, yet it was never observed in the captive population held in Strasbourg. M, N, T, B /O (Dixson, 1977; Nickelson \& Lockard, 1978: mutual lateral embrace; Bernstein \& Baker, 1988).

65. Hand move. An individual starts to reach another -- to touch, grasp, hug or embrace it -- but the gesture is incomplete and there is no contact. This is an affiliative patternn. M, E, N, T (Thierry, 1986)

66. Passive contact. An individual is in contact with another. In huddling, there may be extensive body contact among partners. This is an affiliative contact that may occur during rest or social grooming. $\mathrm{H}, \mathrm{M}$, E, N, O, T, B /O, H / T (Dixson, 1977; Bismark, 1982; Baker \& Estep, 1985; Bernstein \& Baker, 1988).

67. Social grooming. An individual cleans the skin or fur of a partner. The hair is brushed and parted using the hands. Particles are picked using hand or the mouth, teeth or tongue. An individual grooms a passive partner or both mutually groom each other. H, M, E, N, O, T, B /O, H/T (Bramblett, 1973; Lindsay, 1976; Dixson, 1977; Nickelson \& Lockard, 1978; Bismark, 1982; Baker \& Estep, 1985; Bernstein \& Baker, 1988; Thierry et al., 1990; Matsumura, 1991, 1996, 1997; Petit \& Thierry, 1994a; Reed et al., 1997; Aujard et al., 1998).

68. Grooming solicitation. An individual presents a body part (e.g., chest, head, side, excluding hinquarters) to a partner at proximity, or lies against it. This frequently induces grooming by the partner. $\mathrm{H}$, M, E, N, O, T, B /O, H / T (Dixson, 1977; Thierry et al., 1990).

69. Self-grooming. An individual cleans the skin or fur of itself. The hair is brushed and parted using hands. Particles are picked using hand or the mouth. This solitary activity may occur at rest or in the context of social tension. H, M, E, N, O, T, B /O, H/T (Dixson, 1977; Nickelson \& Lockard, 1978; Bismark, 1982; Bernstein \& Baker, 1988).

70. Scratching. A repetitive raking of the skin using fingers of hands or feet. This is a self-directed behavior that may occur before or between approaches and social interactions. M, E, N, T, H $/ \mathrm{T}$ (Nickelson \& Lockard, 1978; Bernstein \& Baker, 1988).

71. Yawn. A gaping movement of the mouth. In a first stage, the mouth is partially opened, forming an oval shape. Then the head is tossed back and the mouth open to the fullest extent before to be rapidly closed with head returning to the normal position. A slow variant of the yawn is associated with resting. In another variant, the tension yawn, gaping is brief and there is no real preliminary stage. This is seen in aroused individuals, it may occur in agonistic contexts and follow support shake or stamping. H, M, E, N, O, T, B /O, H / T (Lindsay, 1976; Dixson, 1977; Nickelson \& Lockard, 1978; Hadidian, 1980; Thierry, 1985, 1986; Reed et al., 1997).

72. Support shake. A violent shaking of an environmental object (e.g., branch or trunk), producing an audible noise. The performer holds the object (e.g., branch) and repeatedly flexes and straightens the limbs. 
This behavior may be followed by yawning. It occurs in conditions of social tension, agonistic contexts or play. It is associated with arousal in the performer and may attract attention to the performer. $\mathrm{M}, \mathrm{E}, \mathrm{N}, \mathrm{O}$, T, B /O, H / T (Dixson, 1977; Nickelson \& Lockard, 1978; Hadidian, 1980; Thierry, 1984, 1985, 1986; Bernstein \& Baker, 1988; Muroyama \& Thierry, 1998).

73. Stamping. A rhythmic trot or a jump followed by an abrupt landing with stiff limbs. This motion occurs in conditions of social tension, agonistic contexts or play. It may be followed by yawning. It is associated with arousal in the performer and may attract attention to it. $\mathrm{E}, \mathrm{N}, \mathrm{O}, \mathrm{T}, \mathrm{B} / \mathrm{O}, \mathrm{H} / \mathrm{T}$ (Bramblett, 1973: demonstration; Dixson, 1977; Hadidian, 1980: stepaway?).

74. Displacement. An individual approaches or contacts an individual, which simultaneously moves away. M, E, N, T, H/T (Bramblett, 1973; Nickelson \& Lockard, 1978; Petit \& Thierry, 1992; Reed et al., 1997: supplant).

75. Pushing. An individual pushes away another using hand or body, transfering momentum. The partner may move or resist. $\mathrm{M}, \mathrm{N}, \mathrm{T}$.

76. Catching at. An individual pulls an object held or an infant carried by another. The action may be soft or vigorous. The partner may tolerate the action, move, turn or push away or protest. $\mathrm{M}, \mathrm{N}, \mathrm{T}$.

77. Take over. An individual takes an object that another holds. This may involve taking of an infant carried on a partner's back. The partner may tolerate the action, move away or protest. M, N, T

78. Shoulder toss. A jerk of the upper part of the body, usually repeated. This occurs as a response to a partner approaching and has a deterrent effect. It may be performed by a mother rejecting infant contact or nipple hold. $\mathrm{M}, \mathrm{N}, \mathrm{T}$.

79. Rubbing ground. A forward sliding movement of the hand on a surface. This behavior is associated with agonistic contexts and acts as a mild threat. N, T.

80. Lunge. An individual performs a jump or short run toward another, generally inducing an agonistic response in it. This behavior is associated to other aggressive patterns. M, E, N, T (Nickelson \& Lockard, 1978; Hadidian, 1980; Petit \& Thierry, 1994a; Matsumura, 1996).

81. Chase. An individual runs after a fleeing individual. The pattern is associated with aggression. $\mathbf{H}, \mathbf{M}$, E, N, O, T, B /O, H / T (Bramblett, 1973; Dixson, 1977; Nickelson \& Lockard, 1978; Thierry, 1985; Matsumura, 1997; Reed et al., 1997; Muroyama \& Thierry, 1998).

82. Slap. An individual hits another with the flat of its hand. This is an aggressive act. M, E, N, T (Hadidian, 1980; Bernstein et al., 1983; Thierry, 1984, 1985; Petit \& Thierry, 1994a; Matsumura, 1996, 1998; Petit et al., 1997; Reed et al., 1997).

83. Grab. An individual vigorously grabs or pulls another. This is an aggressive act. M, E, N, T, H/T (Dixson, 1977; Bernstein et al., 1983; Thierry, 1984, 1985; Petit \& Thierry, 1994a; Matsumura, 1996, 1998; Petit et al., 1997; Reed et al., 1997; Muroyama \& Thierry, 1998).

84. Missed hit. A violent movement of the hand toward another that fails to make contact. This is an aggressive act. $\mathbf{M}, \mathrm{E}, \mathrm{N}, \mathrm{T}$.

85. Bite. An individual bites another, inducing flight, crouch, screaming or counter-attack in it. M, E, N,

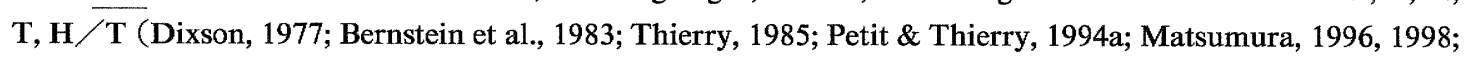
Petit et al., 1997; Reed et al., 1997; Muroyama \& Thierry, 1998).

86. Teeth-grinding. An individual grinds one's teeth, producing a conspicuous sound. This behavior occurs in extreme situations, by case when an individual is separated from others by human beings. $T$. 
87. Crouch. An individual presses the body against the ground with the four limbs flexed in response to an attack or a threat. This submissive act may be accompanied by screaming vocalizations. M, E, N, T (Bramblett, 1973; Dixson, 1977; Thierry, 1985; Petit et al., 1997).

88. Avoidance. An individual walks away when displaced, threatened or attacked. M, E, N, T, B $/ \mathrm{O}$.

89. Flight. An individual runs away when threatened, attacked or chased. $\mathrm{H}, \mathrm{M}, \mathrm{E}, \mathrm{N}, \mathrm{T}, \mathrm{B} / \mathrm{O}, \mathrm{H} / \mathrm{T}$.

90. Flight intention movement. An individual starts to make a body movement away while approached or threatened, but does not move. $\mathrm{M}, \mathrm{E}, \mathrm{N}, \mathrm{T}$.

91. Enlisting. An individual involved in an agonistic interaction seeks aid from another by glancing at it and looking toward the individual to be threatened. This pattern may be used to direct the attention of a potential ally toward an opponent. M, N, T.

92. Parading. A female walks back and forth in front of a male. This may induce mounting by the male especially when performed by females exhibiting perineal swelling. (This behavior does not normally occur in Tonkean and moor macaques but some occurrences might have been observed.) $\mathrm{E}, \mathrm{N}, \mathrm{B} / \mathrm{O}, \mathrm{H} / \mathrm{T}$ (Dixson, 1977: passing back and forth; Bernstein \& Baker, 1988; Baker \& Bynum, 1989; Bynum, 1995).

93. Presentation. An individual raises or orients the hindquarters toward a partner at proximity, and may turn the head toward the partner. In intense presentations (e.g., in estrous females), the head is lowered against the ground, with arms flexed and rump elevated. This may be an invitation to anogenital inspection or exploration, mount, play, grooming or a response to a threat. M, E, N, T, B $/ \mathrm{O}, \mathrm{H} / \mathrm{T}$ (Dixson, 1977; Nickelson \& Lockard, 1978; Thierry, 1984, 1985; Bernstein \& Baker, 1988; Matsumura, 1993; Matsumura \& Watanabe, 1994; Bynum, 1995; Reed et al., 1997; Aujard et al., 1998).

94. Anogenital inspection. An individual closely looks at or smells a partner's anogenital region. In a typical sequence, males inspect an estrous female, then turn the face away while performing a facial expression (e.g., silent bared-teeth, protruded lips) before mounting the female. M, E, N, O, T, H $/ \mathrm{T}$ (Dixson, 1977; Nickelson \& Lockard, 1978; Thierry, 1984, 1986; Bernstein \& Baker, 1988; Matsumura, 1993; Aujard et al., 1998).

95. Anogenital exploration. An individual fingers or orally touches a partner's anogenital region. M, E, N, O, T, H/T (Dixson, 1977; Thierry, 1984; Aujard et al., 1998).

96. Leg grip. A mounting individual grasps the mountee's legs with its feet. Occasionally, only one leg is grasped. M, E, N, O, T, B /O, H /T (Dixson, 1977; Bernstein \& Baker, 1988).

97. Mount. An individual climbs ventrodorsally upon a standing partner. The mounter may or may not grip the legs of the partner. The behavior may represent a copulation or an affiliative interaction. $\mathrm{M}, \mathrm{E}, \mathrm{N}, \mathrm{O}, \mathrm{T}$, B /O, H / T (Dixson, 1977; Nickelson \& Lockard, 1978; Thierry, 1984, 1986; Bernstein \& Baker, 1988; Matsumura, 1993, 1994; Matsumura \& Watanabe, 1994; Petit \& Thierry, 1994a; Bynum, 1995; Reed et al., 1997; Aujard et al., 1998; Matsumura \& Okamoto, 1998).

98. Disoriented mount. An individual climbs upon a partner in a position not suited for intromission: either frontally, from the side, against the back or a lying individual, or sitting on the back. M, N, T.

99. Erection. An erection of the penis. It may occur during play, social grooming, mounting or genital self-stimulation. M, E, N, O, T, H/T (Dixson, 1977).

100. Reaching back. A mounted individual reaches back with a hand toward the mounter. It may grasp the mounter's limb, pat or grasp its face, penis or scrotum, or perform only a motion of the limb. This may be accompanied by looking backward. M, E, N, T, B /O (Dixson, 1977; Bernstein \& Baker, 1988; Baker et al., 
1995).

101. Intromission. An insertion of the erect penis in the female genitals during mounting. M, E, N, O, T, B /O, H/T (Dixson, 1977; Bynum, 1995; Reed et al., 1997; Aujard et al., 1998)

102. Thrust. A back and forth pelvic motion. A series of thrusts is generally performed by a mounting individual. It may also occur in individuals performing disoriented mounts or in females self-stimulating their genitals against a support. M, E, N, O, T, B /O, H / T (Dixson, 1977; Bynum, 1995; Reed et al., 1997; Aujard et al., 1998).

103. Pause. A pause in pelvic thrusting accompanied by body rigidity. It may be accompanied by body tremor associated to ejaculation. This pattern occurs during mounting. M, E, N, O, T, H $/$ T (Dixson, 1977; Bynum, 1995).

104. Ejaculation. An emission of semen, occurring during genital self-stimulation or mounting. M, E, N, O, T, H/T (Dixson, 1977; Nickelson \& Lockard, 1978; Bernstein \& Baker, 1988; Matsumura, 1991; Reed et al., 1997; Aujard et al., 1998; Matsumura \& Okamoto, 1998).

105. Post-mount flight. In mating, the female runs away some meters from the male immediately after dismount. In $M$. nigra, this is most frequently displayed by females mating with low-ranking males. In $M$. maurus, the male may also run away after mating. M, E, N, T, H/T (Dixson, 1977).

106. Eating genital secretion. An ingestion of semen or female genital secretion following ejaculation. $M$, N, T.

107. Urine testing. The licking of urine on the ground or, during micturition by another, an individual opens the mouth to let the urine flow on its tongue. T.

108. Genital self-stimulation. An individual manipulates its own genitals. This may lead to erection and ejaculation in males. This may also be performed by rubbing the genitals against a support. M, E, N, T, H $/ \mathrm{T}$ (Dixson, 1977).

109. Examination. An individual manipulates the body of another. This is often directed toward infants and may include pulling the limbs, handling the genitals and lifting or turning over. M, N, T (Dixson, 1977; Preuschoft, 1995; Matsumura, 1997).

110. Attracting. An individual brings another toward itself with hand. This may be a mother attracting an infant on its belly. This may be also an individual pulling the partner's fur to initiate contact or an affiliative interaction, as in grooming or play. M, N, T (Dixson, 1977).

111. Pick up. An individual approaches and picks up an infant that is moving freely. M, E, N, T.

112. Clinging. An infant clings with hands and feet to the ventral surface of the holder, grasping the fur on the sides of its body. M, E, N, T, B $/ \mathrm{O}, \mathrm{H} / \mathrm{T}$.

113. Ventral contact. An infant maintains contact with the ventral surface of an older individual. There is no clasp by one or the other partner. The infant may face the ventral surface of its partner or sit sideways or outward. M, E, N, T, H $/$ T.

114. Cradling. A seated individual holds an infant on its ventral surface while enclosing it with arms and legs, or clasping it with one or both hands. $\mathrm{M}, \mathrm{E}, \mathrm{N}, \mathrm{T}, \mathrm{B} / \mathrm{O}, \mathrm{H} / \mathrm{T}$.

115. Carriage. An individual transports an infant in a ventral position from one location to another. The infant may be clinging and / or the carrier may support it with one or both hands. Occasionally, the carrier supports the infant clinging to an odd part of the body (e.g., the arm). M, E, N, T, B $/ \mathrm{O}, \mathrm{H} / \mathrm{T}$.

116. Dorsal carriage. An infant is transported on the back of a carrier. The infant holds on, grasping the 
fur of the carrier. In the usual position, the infant lies forward on the loins or the nape. It may also be incorrectly oriented. Infants rarely sit on the carrier's back jockey-style. Dorsal carriage was never observed in $M$. nigra. T.

117. Climbing. An immature individual climbs over an older individual. This may be an infant crawling and exploring on any part of its body. That also may be an immature jumping on the back of a mating individual. M, N, T (Dixson, 1977; Thierry, 1986; Matsumura, 1994).

118. Rooting. A clinging infant moves its head from side to side, with mouth open, in search of the nipple. $\mathrm{M}, \mathrm{N}, \mathrm{T}$.

119. Nipple holding. An infant holds a nipple in its mouth. It may or may not suck. M, E, N, T.

120. Nipple manipulation. An infant manipulates the nipple of a carrier. M, N, T.

121. Nipple deterrence. An individual prevents access or removes the nipple from an immature's mouth. A mother may deter the approach of an infant with the forearm, and may withdraw the nipple by pushing the infant, lifting its arm, or jerking backward and away from the infant. $\mathrm{M}, \mathrm{N}, \mathrm{T}$.

122. Infant removal. An individual pulls an infant off itself and pushes it away to break contact. M, N, T.

123. Restraint. An individual prevents an infant from leaving or interacting with another partner. The holder clasps the infant or retains it by a limb. M, N, T.

124. Monitoring. An individual maintains close proximity or contact with a moving infant. A mother may place one hand on the infant. N, T.

125. Jerk. A spasmodic jerking of the shoulders and trunk that is often performed in series and accompanied by gecker and screaming vocalizations. Jerks are performed by immatures seeking contact from an ignoring or rejecting individual. This may be a response to a mother's behavior, including contact or nipple deterrence, pushing away, and hitting or biting punishment. The jerk often induces retrieving by the mother or another individual, and grunting in surrounding individuals. M, N, T.

126. Struggle. An individual struggles to break contact and escape from an individual holding it. This may be a response to a mother's restraint or another partner's examination or taking over. M, N, T.

127. Invitation twist. An individual moves frenetically, as in turns around or shakes the head up and down to attract the attention of a newborn. M, T.

128. Mount walk. Two individuals of different size walk together, one over the other. T.

\section{Play Patterns}

129. Play motion. An individual engages in relaxed and more or less exuberant patterns including loping gait, running, climbing, swinging, rolling, sliding, jumping, walking on hands, bouncing, pirouetting, toppling, uncoordinate moving, stamping, support shaking, handling, dragging or throwing an object. Any of these patterns may appear in solitary or social play. M, E, N, T (Nickelson \& Lockard, 1978; Preuschoft, 1995).

130. Play contact. An individual contacts another in the context of play. This may include touching, slapping, bumping, jostling, pushing, grasping, catching, pulling, nibbling, dragging, lifting, climbing or leaping over the partner, along with other patterns possibly occurring outside the context of play (e.g., mount, mouth approach). These patterns are accompanied by silent bared-teeth and play postures. M, E, N, T, B $/ \mathrm{O}$ (Nickelson \& Lockard, 1978; Baker \& Estep, 1985; Preuschoft, 1995).

131. Play initiation. An individual approaches another to initiate play. This may employ a variety of patterns: direct looking, head tilting, looking backward, passing by, crouching, missing hit, silent bared-teeth, 
scalp retraction, protruded lips displays and any play motions or contacts. While these patterns are playful, many of these patterns may be seen outside the context of play. M, E, N, T.

132. Sparring. Two individuals exchange playful slaps, grasps and missing hits with silent bared-teeth and panting grunts. Partners may be sitting or standing bipedally. There is no extensive body contact between them. M, E, N, T.

133. Wrestle. Two individuals are engaged in prolonged, playful body contact while rolling and mutually grasping, hugging and nibbling each other. Partners frequently emit silent bared-teeth and panting grunts. One of them sometimes holds an object. M, E, N, T, B /O (Nickelson \& Lockard, 1978; Thierry, 1984; Baker \& Estep, 1985; Petit \& Thierry, 1992; Preuschoft, 1995).

134. Play chase. An individual runs after a partner. The chase may be interspersed with panting grunts, scalp retraction, silent bared-teeth and protruded lips displays, and other patterns like play motions and contacts. One partner may carry or drag an object. M, E, N, T (Nickelson \& Lockard, 1978; Baker \& Estep, 1985; Petit \& Thierry, 1992; Preuschoft, 1995; Reed et al., 1997).

135. Play flight. An individual flees in response to an approach, a jump or a play chase by a partner, or to induce play chasing in it. The flight may be interspersed with panting grunts, scalp retraction, silent bared-teeth and protruded lips displays, and other patterns like play motions and contacts. One partner may carry or drag an object. M, E, N, T (Petit \& Thierry, 1992; Reed et al., 1997).

136. Synchronous play. Two individuals engage in simultaneous play motions in full view of each of them, or attempt to play with the same object at the same time. $\mathrm{M}, \mathrm{N}, \mathrm{T}$.

137. Teasing. An individual addresses repeated play contacts toward a partner while the latter ignores them or flees, screams or protests aggressively. The contacting individual does not emit aggressive facial expressions or vocalizations, and may or not show the silent bared-teeth display. M, E, N, T (Preuschoft, 1995).

\section{Special Triadic Interactions}

138. Joint play. An individual joins partners involved in social play (wrestle, sparring, play-chase and -flight). Many individuals may be simultaneously involved. M, E, N, T.

139. Joint teasing. An individual joins an individual teasing another. Several immatures may surround, grab, slap and nibble another, which screams and crouches or flees. N, T (Muroyama \& Thierry, 1996: polyadic teasing).

140. Supplantation. An individual threatens or displaces another who is sitting in contact or interacting with a third individual and takes its place. M, E, N, T (Thierry et al., 1990).

141. Redirected aggression. An individual threatened or attacked by another shows aggression toward a third individual. The first aggressor may transfer aggression toward the latter. M, N, T (Dixson, 1977; Thierry, 1985; O’Brien \& Kinnaird, 1997).

142. Aggressive intervention. An individual intervenes in an agonistic interaction by showing aggression toward one of the opponents. M, N, T (Petit \& Thierry, 1994b; Matsumura, 1996; Petit et al., 1997; Matsumura, 1998).

143. Peaceful intervention. An individual intervenes in an agonistic interaction in directing affiliative behavior patterns (e.g., clasp, mount, lipsmack) toward one of the opponent. This may stop aggression. M, N, T (Thierry, 1984; Petit \& Thierry, 1994b; O'Brien \& Kinnaird, 1997; Petit et al., 1997). 
144. Interposition. An individual interposes itself between two conspecifics. It separates an adult male from a female in estrus, or it intervenes in an agonistic interaction in putting itself between both opponents. T, N (Petit \& Thierry, 1994b).

145. Protection seeking. An individual threatened or attacked by another approaches and contacts a third individual: it may contact, clasp, groom and utter vocalizations (e.g., tonal scream, whimpering grunt) toward the latter. M, N, T (Thierry, 1984).

146. Aggressive interference in mount. An individual approaches a mating pair and shows aggression toward them, sometimes disrupting copulation. M, N, T (Thierry, 1986; Aujard et al., 1998).

147. Affiliative interference in mount. An individual approaches a mating pair and directs affiliative behavior patterns toward them (e.g., clasp, lipsmack, soft grunt). M, E, N, T, B /O, H / T (Dixson, 1977; Thierry, 1986; Baker \& Bynum, 1989; Petit \& Thierry, 1992, Matsumura, 1994; Bynum, 1995; Matsumura \& Okamoto, 1998).

148. Affiliative interference in clasp. An individual approaches partners exchanging grasps, hugs or embraces and directs affiliative behavior patterns toward them (e.g., clasp, lipsmack, soft grunt). T (Thierry, 1984, 1986).

149. Collective arousal. Many individuals are excited. They move, emit and exchange numerous affiliative behavior patterns, including clasp, silent bared-teeth, lipsmack, soft grunt, affiliation call, twit and expressive run. Such an interaction may follow an important polyadic conflict, it may occur at the reunion of previously separated partners or precede an awaited food distribution. M, E, N, T, H/T (Matsumura, 1991; Petit \& Thierry, 1992).

\section{DISCUSSION}

Sulawesi macaques share a number of behaviors with other members of the genus Macaca. Therefore, our comments will focus on the patterns that differ between Sulawesi taxa or distinguish them from other macaques. When discussing variations, however, it should be kept in mind that the length of observation devoted to each of the seven taxa turned out to be strongly unequal (Table 1). M. nigra and $M$. tonkeana are by far the best known, each taxon has benefited from more than 10,000 hrs of observation at close distance. The amount of knowledge is worthy for $M$. maurus too albeit to a lesser extent. In contrast, few studies have tackled the behavior of $M$. hecki and $M$. nigrescens in the field, and populations of $M$. brunnescens and $M$. ochreata remain mostly unknown both in the wild and in captivity.

Among the behavior patterns that differentiate Sulawesi macaques from other members of their genus, the silent bared-teeth display is one of the most conspicuous. Most macaques bare the teeth to express submission (Hinde \& Rowell, 1962; Bertrand, 1969; de Waal et al., 1976; de Waal \& Luttrell, 1985). In M. sylvanus and M. silenus, which belong to the same phyletic group than Sulawesi macaques, this display may have an affiliative component (Preuschoft, 1995; Johnson, 1985). In Sulawesi macaques, it advertises the emitter's peaceful intention and promotes affiliative interactions. The jaw may be closed or open; in the latter case, the facial expression is indistinguishable from the relaxed open-mouth display peculiar to play context in macaques. It has been hypothesized that the merging between silent bared-teeth and relaxed display is related to a weak dominance asymmetry that would make submissive signals occurring outside the context aggression of little use (Thierry et al., 1989; Petit \& Thierry, 1992; Preuschoft, 1995). While dominance relationships can be clearly recognized in known Sulawesi taxa (Thierry et al., 1994; Reed et al., 1997), dominance among 


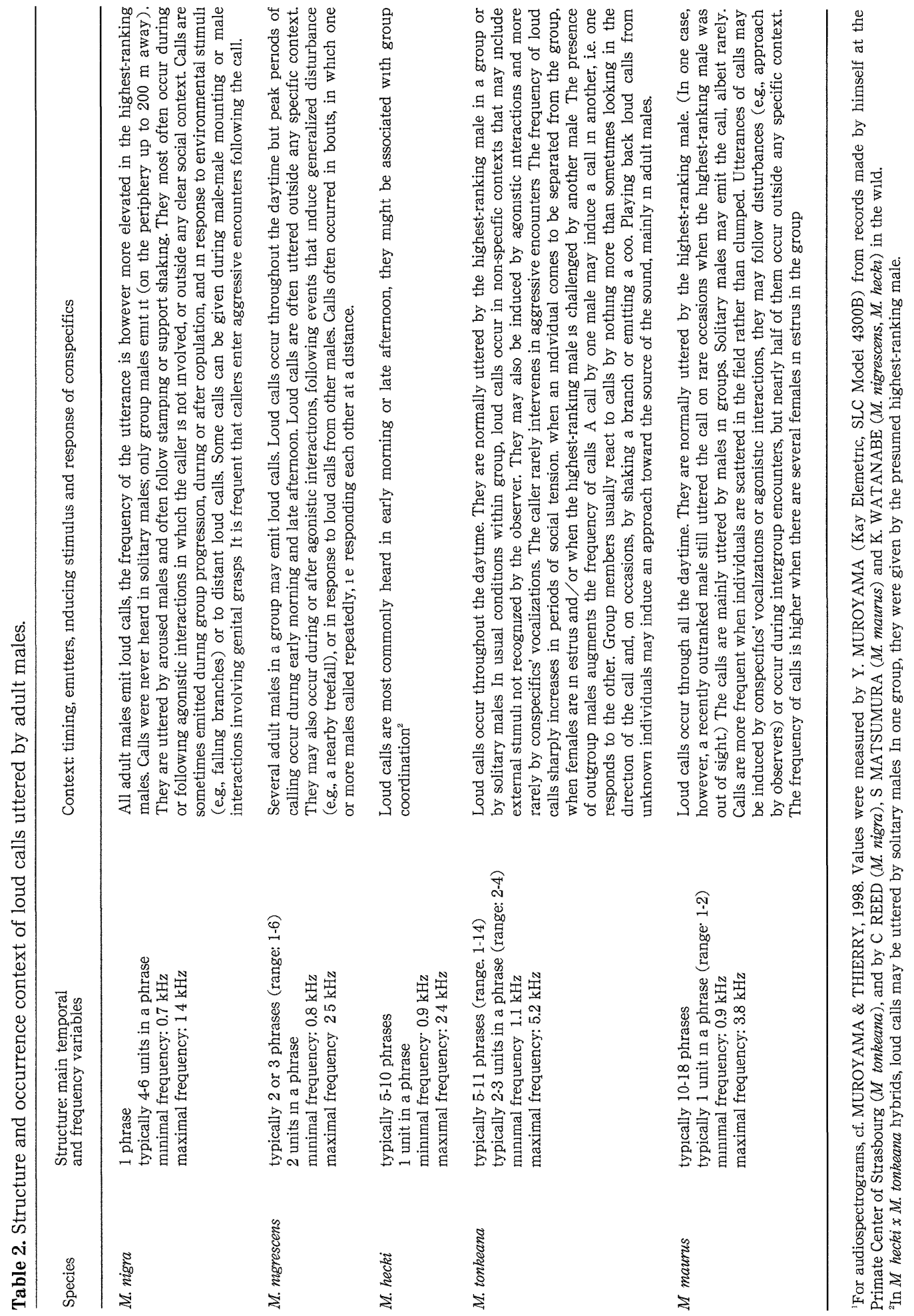


females appears relaxed in comparison to many other macaques (Thierry, 1985; Thierry et al., 1990, 1994; Matsumura, 1996; O'Brien \& Kinnaird, 1997; Matsumura, 1998).

There is no silent threat with mouth fully open in known Sulawesi taxa. In mild threats, the mouth is half open, lips are horizontally retracted and a shrilling vocalization usually occurs. However, in more intense threats, the lips are fully retracted, horizontally and vertically. To distinguish such threats from the silent bared-teeth display, it is necessary to account for other behavior patterns, i.e. accompanying gaze, posture and vocalization. As noted once by Darwin (1872), there are strong similarities between both facial expressions; this contradicts his own antithesis principle, which assumes that displays of opposite meanings should be of opposite forms. This is all the more so if we consider the existence of the silent bared-teeth jaw movement, which until now was reported only in $M$. nigra males in the sexual context. Two other features that clearly do not follow the antithesis principle are the lipsmack and the jaw movements displays. The reassuring nature of the lipsmack in Sulawesi macaques appears close to that observed in other macaques. The jaw movement display is a threat that was reported for $\boldsymbol{M}$. nigra and $M$. tonkeana. It was previously named an "aggressive lipsmack" (Bernstein, 1970a; Dixson, 1977; Bernstein \& Baker, 1988).

The communicative repertoire of Sulawesi macaques appears especially rich. Individuals are particularly expressive as judged by their use of communication signals that are uncommon in other macaques: stamping, expressive run, turning face away, panting grunt, affiliation call. Interestingly, several of these behaviors were described in species belonging to the same phyletic group of macaques: all these behaviors exist in $M$. silenus, and panting grunts and a pattern similar to turning face away (head-flagging) have been reported in $\boldsymbol{M}$. sylvanus (Hohmann \& Herzog, 1985; Johnson, 1985; Lindburg et al., 1985; Preuschoft, 1995; Abegg et al., 1996). The distribution of other behaviors is less consistent. Parading is known in M. silenus (Lindburg et al., 1985) and some Sulawesi taxa. The protruded lips display is reported in M. nemestrina (Kaufman \& Rosenblum, 1966 ; van Hooff, 1967; Maestripieri, 1996) and M. silenus (Johnson, 1985; Lindburg et al., 1985), as in M. tonkeana and M. maurus, but it seems not to exist in $M$. nigra. An estrus call is described in M. nemestrina, M. silenus, M. sylvanus, and in M. tonkeana and M. nigra as well (Deag, 1974; Lindburg et al., 1985; Masataka \& Thierry, 1993; Aujard et al., 1998), however it was not recognized in M. maurus and $M$. nigrescens.

The qualitative development of affiliative behaviors appears linked to a high frequency of positive social interactions in Sulawesi taxa, at least for those in which social patterns have been quantified (Thierry, 1984; Thierry et al., 1994; Matsumura, 1996; O’Brien \& Kinnaird, 1997). Clasping behaviors are especially frequent and varied. Many grasps, hugs and embraces occur in various forms (Thierry, 1984; Matsumura, 1991) but some appear more ritualized: the genitals grasp and the lateral embrace in $M$. nigra and other taxa (Dixson, 1977; Reed et al., 1997). A rich repertoire of affiliative contacts coupled with relaxed dominance allows the conveyance of subtle messages. Genitals grasps among $M$. nigra males could fulfill the same negociating function as the greeting behavior in baboons (Papio spp.) (Smuts \& Watanabe, 1990; Colmenares, 1991; Reed et al., 1997). And some clasps and nibblings that follow contests in $M$. tonkeana might convey both an affiliative and assertive meaning; they have been once labeled "affinitive punishments" (Thierry et al., 1994).

A high rate of involvement in polyadic interactions might be related to the above features. Interventions may be agonistic as in joint teasing but they are often affiliative, as in interferences of immatures in mounts or in clasps (Thierry, 1986; Matsumura, 1994; Thierry et al., 1994). Peaceful interventions in conflicts are especially frequent in known Sulawesi taxa (Petit \& Thierry, 1994; O’Brien \& Kinnaird, 1997); in wild $M$. 
nigra, many individuals at time are liable to intervene peacefully in conflicts (Kinnaird \& O'Brien, personal observation). Observing three and more immatures mingled in lengthy wrestles is common in $\boldsymbol{M}$. tonkeana (Demaria \& Thierry, unpublished data) and Macaca nigra (Kinnaird \& O'Brien, personal observation).

Instances of collective arousal stand as another spectacular example of polyadic interaction. In such noisy events, numerous individuals continously exchange affiliative communication signals and contacts during periods that may last until $10 \mathrm{~min}$. This behavior occurs when individuals are reunited after a separation or after a conflict having involving many individuals. In one case in wild $M$. tonkeana, group members gathered after crossing a road which the observer's presence had prevented them doing that for more than an hour. The group then entered into in a long episode of collective arousal (Thierry, personal observation). Collective arousal may also occur before an awaited food distribution. Such behavior is close to those previously described in chimpanzees (Pan troglodytes) as "celebration" (de Waal, 1996).

At this stage, a primary conclusion is that Sulawesi taxa share most of the behavior patterns of their repertoire, with the caveat that we lack extensive information for some of the taxa. While there is an absence of comparable records for many vocalizations, a notable exception is the loud call emitted by adult males. In M. tonkeana, we first observe that the loud call is composed of several modulated units organized in different phrases (Table 2). Two other vocalizations share the same modulated units, namely the twit, which is composed of one unit and is uttered by individuals participating in exceptionally intense social interactions, and the cackle, which is composed of two similar units. The cackle also occurs in intense and mainly agonistic interactions, but is almost exclusively heard in young males at least four years old. These two vocalizations seem to make up an ontogenetic continuum with the loud call, itself usually composed of several phrases of 2 or 3 similarly modulated units (Table 2 ). The earliest utterance ever heard of a loud call was composed of only two phrases and was performed by an 8-year old male (Thierry, personal observation). The loud call appears in same situations as the twit and the cackle. In addition, it may be detached from such situations and occur outside the context of social interaction.

When looking at the other taxa, it appears that their different loud calls are variations of the repetition of a main fundamental modulated unit according to different temporal distributions (Table 2). The call of $\boldsymbol{M}$. nigra consists of a single phrase composed of several units - it could be said alternatively that it comprises several 1-unit phrases. In $\boldsymbol{M}$. nigrescens, there are some 2-unit phrases separated by pauses of $3 \mathrm{sec}$. In $\boldsymbol{M}$. hecki, several phrases are separated by intervals less than 1-sec long like in $M$. tonkeana. However, the phrases are composed of 1 unit in the former while they are usually composed of 2 or 3 units in the latter. A clinal variation in the number and temporal distribution of units in a call is therefore apparent from the end of the northern peninsula to the center of Sulawesi (Fig. 1). This is consistent with an increase in frequency level of the call from north to south (Table 2).

With regard to M. maurus, in the southwest, the loud call is also constituted of several phrases typically composed of 1 unit and repeated at intervals less than 1-sec long -- shorter than in $M$. hecki and M. tonkeana (Muroyama \& Thierry, 1998). There is no argument to assert whether it represents an extension of the previous north-south cline or belongs to another gradient related to $M$. tonkeana. The same holds for loud calls heard in the taxa from the southeastern part of the island; in M. ochreata and M. brunnescens, calls are constituted of several phrases separated by intervals less than 1-sec long (Watanabe, unpublished data) but no more information is available. Such patterns are in agreement with the radiation model proposed for the evolutionary differentiation of Sulawesi taxa, which assumes that speciation pathways followed the 
geographical branching of the island in several arms (Fooden, 1969; Albrecht, 1978; Kawamoto, 1996). However, as is true for morphological and molecular variables, more data about possible clines are needed to state whether the radiation originates from a proto-tonkeana like stock (Fooden, 1969; Kawamoto, 1996) or from ancestors closer to other taxa (Albrecht, 1978; Groves, 1980; Evans et al., 1999).

While only solitary males or the highest-ranking ones may emit the calls in $M$. tonkeana and $M$. maurus, it may be uttered by any males in $M$. nigrescens and $M$. nigra. The calls appear less differentiated in the latter taxon both in form and function, they are also less sharp and loud for $M$. nigra than for other taxa. On the basis of morphology, M. nigra is the most derived taxon in the island (Fooden, 1969; Albrecht, 1978). We may conclude that a dedifferentiation of loud calls likely occurred during evolution in $M$. nigra (and possibly to a lesser extent in $M$. nigrescens). Such a view is consistent with the fact that loud calls are likely a primitive character in the silenus group: M. silenus and M. pagensis (Siberut island) emit loud calls unlike other macaque species (Watanabe, 1979; Whiten \& Whiten, 1982; Hohmann \& Herzog, 1985; Masataka \& Thierry, 1993). Although different in acoustic structure, their loud calls are composed of repeated segments like those of Sulawesi macaques.

A function of loud calls is possibly the spacing and recognition between males and groups (Muroyama \& Thierry, 1998; but see Okamoto \& Matsumura, 1998; Kinnaird \& O'Brien, 1999). In comparison to the loud calls described in other species, the frequency level of calls is unusually high in Sulawesi macaques. The use of short wavelengths does not favor the transmission and perception of vocalizations through vegetation, especially in a noisy environment where cicadas and birds also emit high-frequency sounds (Waser \& Waser, 1977; Mitani \& Stuht, 1998). A possible explanation may be found in the hilly nature of the island: sharp vocalizations may be carried at great distances from an hillside to another, passing over the forest. Yet loud calls have also an intragroup function (Masataka \& Thierry, 1993; Okamoto \& Matsumura, 1998). In M. nigra, it was hypothesized that loud calls primarily signal the male's willingness to intervene in conflicts (Kinnaird \& O'Brien, 1999). As for some other differences found among Sulawesi taxa, it remains to know whether they reflect the incompleteness of our explanations or genuine interspecific variation.

\section{ACKNOWLEDGEMENTS.}

The authors thank R. Lee, K. Okamoto and C. Reed for kindly sharing information and data. They acknowledge the sponsorship and assistance of J. Supriatna, J. Sugardjito, H. Pramono, B. Suryobroto, N. Soegiri, O. Soemarwoto, E. Brotoisworo, D. Darnaedi, S. Wiryoatmodjo, C. Southwick and J. Erwin. The following public and private organizations have supported the authors' work. S. Matsumura \& K. Watanabe: Inpex Foundation, Grant-in-Aid for Overseas Scientific Surveys from Ministry of Education, Science and Culture, Japan. M.F. Kinnaird \& T.G. O’Brien: Wildlife Conservation Society, National Geographic Society, Wenner-Gren Anthropological Foundation. Y. Muroyama: Fyssen Foundation, Travel Awards for Overseas Research from the Nakayama Foundation for Human Science, Awards for Overseas Scientific Survey from Primate Society of Japan. S. Baker: World Wildlife Fund, National Geographic Society, James Madison University, Chicago Zoological Society, LABS/Yemassee Primate Center, National Science Foundation, National Institutes of Health. E.L. Bynum: Fulbright-Hays Doctoral Dissertation Research Abroad Fellowship, National Science Foundation Doctoral Dissertation Improvement Grant, Wenner-Gren Foundation for Anthropological Research, Douroucouli Foundation, Leakey Foundation, National Geographic Society, Chicago Zoological Society, World Wildlife Fund, Williams Fund of the Department of 
Anthropology at Yale University, Sigma Xi, the Enders fellowship of Yale University, American Women in Science. The work was made possible by the Centre National de la Recherche Scientifique (CNRS, France), the Indonesian Institute of Science (LIPI) and the Indonesian Directorate of Forest Conservation and Nature Protection (PHPA).

\section{REFERENCES}

Abegg C, Thierry B, Kaumanns W 1996: Reconciliation in three groups of lion-tailed macaques (Macaca silenus). Int. J. Primatol. 17: 803-816.

Albrecht GH 1978: The Craniofacial Morphology of the Sulawesi Macaques: Multivariate Approach to Biological Problems. Karger, Basel.

Aujard F, Heistermann M, Thierry B, Hodges JK 1998: The functional significance of behavioral, morphological and endocrine correlates across the ovarian cycle in semi-free ranging female Tonkean macaques. Am. J. Primatol. 46: 285-309.

Baker S, Bynum EL 1989: Preliminary observations of captive Sulawesi macaques: Macaca maurus and Macaca ochreata $x$ brunnescens. Am. J. Primatol. 18: 133.

Baker SC, Estep DQ 1985: Kinship and affiliative behavior patterns in a captive group of Celebes black apes (Macaca nigra). J. Comp. Psychol. 99: 356-360.

Baker SC, Mulligan BE, Supriatna J, Pramono H 1995: Contexts and acoustic characteristics of "adult male calls" of Macaca nigrescens. Am J Primatol. 36: 109.

Bernstein IS 1970a: Some behavioral elements of the Cercopithecoidea. In Napier JR, Napier PH (eds): Old World Monkeys. Academic Press, New York, pp. 263-295.

Bernstein IS 1970b: Primate status hierarchies. In Rosenblum LA (ed): Primate Behavior Vol 1. Academic Press, New York, pp. 71-109.

Bernstein IS, Baker SC 1988: Activity patterns in a captive group of Celebes black apes (Macaca nigra). Folia Primatol. 51: 61-75.

Bernstein IS, Williams L, Ramsay M 1983: The expression of aggression in Old World monkeys. Int. J. Primatol. 4: 113-125.

Bertrand M 1969: The Behavioral Repertoire of the Stumptail Macaque. Karger, Basel.

Bismark M 1982: Ekologi dan tingkahlaku Macaca nigrescens di Suaka Margasatwa Dumoga, Sulawesi Utara. Balai Penilitian Hutan Rep 382.

Bramblett CA 1973: Social organization as an expression of role behavior among Old World monkeys. Primates 14: 101-112.

Bynum EL 1995: Hybridization between $M$. tonkeana and $M$. hecki in Central Sulawesi, Indonesia. New Haven, Yale University, PhD thesis, 1995.

Bynum EL, Bynum DZ, Froehlich JW, Supriatna J 1997: Revised geographic ranges and hybridization in Macaca tonkeana and Macaca hecki. Trop. Biodiv. 4: 275-283.

Bynum, EL, Bynum DZ, Supriatna J 1997: Confirmation and location of the hybrid zone between wild populations of Macaca tonkeana and Macaca hecki in Central Sulawesi, Indonesia. Am. J. Primatol. 43: 181-209.

Camperio Ciani A, Stanyon R, Scheffrahn W, Sampurno B 1989: Evidence of gene flow between Sulawesi macaques. Am. J. Primatol. 17: 257-270.

Coehlo AM, Bramblett CA 1989: Behaviour of the genus Papio: ethogram, taxonomy, methods and comparative measures. In Seth PK, Seth S (eds): Perspectives in Primate Biology Vol 3. Today \& Tomorrow, New Delhi, pp. 117-140.

Colmenares F 1991: Greeting behaviour between male baboons: oestrous females, rivalry and negotiation. Anim. Behav. 41: 49-60.

Darwin C 1872: The Expression of the Emotions in Man and Animals. John Murray, London (Reprinted: Chicago, University of Chicago Press, 1965).

De Waal FBM 1996: Good Natured. Harvard University Press, Cambridge, MA.

De Waal FBM, Luttrell LM 1985: The formal hierarchy of rhesus macaques: An investigation of the bared-teeth display. Am. J. Primatol. 9: 73-85.

De Waal FBM, van Hooff JARAM, Netto WJ 1976: An ethological analysis of types of agonistic interaction in a captive group of Java-monkeys (Macaca fascicularis). Primates 17: 257-290.

Deag JM 1974: A Study of the Social Behaviour and Ecology of the Wild Barbary Macaque Macaca sylvanus L. University of Bristol, PhD thesis.

Delson E 1980: Fossil macaques, phyletic relationships and a scenario of deployment. In Lindburg DG (ed): The Macaques: Studies in Ecology, Behavior, and Evolution. Van Nostrand Rheinhold, New York, pp. 10-30.

Dixson AF 1977: Observations on the displays, menstrual cycles and sexual behaviour of the "black ape" of Celebes (Macaca nigra). J. Zool 182: 63-84. 
Evans BJ, Morales JC, Supriatna J, Melnick DJ 1999: Origin of the Sulawesi macaques (Cercopithecidae: $M a c a c a$ ) as suggested by mitochondrial DNA phylogeny. Biol. J. Lin. Soc. 66: 539-560.

Fooden J 1969: Taxonomy and Evolution of the Monkeys of Celebes (Primates: Cercopithecidae). Karger, Basel.

Fooden J 1976: Provisional classification and key to the living species of macaques (Primates: Macaca). Folia Primatol. 25: 225-236.

Fooden J, Lanyon SM 1989: Blood-protein allele frequencies and phylogenetic relationship in Macaca: a review. Am. J. Primatol. 17: 209-241.

Froehlich JW, Supriatna J 1996: Secondary intergradation between Macaca maurus and M. tonkeana in South Sulawesi, and the species status of $M$. togeanus. In Fa JE, Lindburg DG (eds): Evolution and Ecology of Macaque Societies. Cambridge University Press, Cambridge, pp. 43-70.

Groves CP 1980: Speciation in Macaca: the view from Sulawesi. In Lindburg DG (ed): The Macaques: Studies in Ecology, Behavior, and Evolution. Van Nostrand Rheinhold, New York, pp. 84-124.

Hadidian J 1980: Yawning in an Old World monkey, Macaca nigra (Primates: Cercopithecidae). Behaviour 75: $134-147$.

Harihara S, Kawamoto Y, Suryobroto B, Omoto K, Takenaka O, 1996: Differentiation of mitochondrial DNA types in Sulawesi macaques. In Shotake T, Wada K (eds): Variations in the Asian Macaques. Tokai University Press, Tokyo, pp. 67-88.

Hinde RA, Rowell TE 1962: Communication by postures and facial expressions in the rhesus monkey (Macaca mulatta). Proc. Zool. Soc. Lond. 138: 1-21.

Hoelzer GA, Melnick DJ 1996: Evolutionary relationships of the macaques. In Fa JE, Lindburg DG (eds): Evolution and Ecology of Macaque Societies. Cambridge University Press, Cambridge, pp. 3-19.

Hohmann GM, Herzog MO 1985: Vocal communication in lion-tailed macaques (Macaca silenus). Folia Primatol. 45: 148-178.

Johnson PC 1985: Notes on the ethogram of captive lion-tailed macaques. In Heltne PG (ed): The Lion-tailed Macaque. Alan R Liss, New York, pp. 238-263.

Kaufman IC, Rosenblum LA 1966: A behavioral taxonomy for Macaca nemestrina and Macaca radiata: Based on longitudinal observation of family groups in the laboratory. Primates 7: 205-258.

Kawamoto Y 1996: Population genetic study of Sulawesi macaques. In Shotake T, Wada K (eds): Variations in the Asian Macaques. Tokai University Press, Tokyo, pp. 67-88.

Kinnaird MF, O’Brien TG 1999: A contextual analysis of the loud call of the Sulawesi crested black macaque Macaca nigra. Trop. Biodiv. $6(1 \& 2): 37-42$.

Lindburg DG 1990: Proceptive calling by female lion-tailed macaques. Zoo. Biol. 9: 437-446.

Lindburg D, Shideler S, Fitch H 1985: Sexual behavior in relation to time of ovulation in the lion-tailed macaque. In Heltne PG (ed): The Lion-tailed Macaque. Alan R Liss, New York, pp. 131-148.

Lindsay NBD 1976: Celebesian black apes (Cynopithecus n niger). Ann. Rep. Jersey Wildl. Pres. Trust 13: 56-61.

Maestripieri D 1996: Gestural communication and its cognitive implications in pigtail macaques (Macaca nemestrina). Behaviour 133: 997-1022.

Masataka N, Thierry B 1993: Vocal communication in Tonkean macaques in confined environments. Primates 34: 169-180.

Matsumura S 1991: A preliminary report on the ecology and social behavior of moor macaques (Macaca maurus) in Sulawesi, Indonesia. Kyoto Univ. Overseas Res. Rep. Stud. Asian Non-human Primates 8: 27-41.

Matsumura S 1993: Female reproductive cycles and the sexual behavior of moor macaques (Macaca maurus) in their natural habitat, South Sulawesi, Indonesia. Primates 34: 99-103.

Matsumura S 1994: Affiliative mounting interference in Macaca maurus. Kyoto Univ. Overseas Res. Rep. Stud. Asian Non-human Primates 9: 1-5.

Matsumura S 1996: Postconflict affiliative contacts between former opponents among wild moor macaques (Macaca maurus). Am. J. Primatol. 38: 211-219.

Matsumura S 1997: Mothers in a wild group of moor macaques (Macaca maurus) are more attractive to other group members when holding their infants. Folia Primatol. 68: 77-85.

Matsumura S 1998: Relaxed dominance relations among female moor macaques (Macaca maurus) in their natural habitat, South Sulawesi, Indonesia. Folia Primatol. 69: 346-356.

Matsumura S, Okamoto K 1997: Factors affecting proximity among members of a wild group of moor macaques during feeding, moving, and resting. Int. J. Primatol. 18: 929-940.

Matsumura S, Okamoto K 1998: Frequent harassment of mounting after a takeover of a group of moor macaques (Macaca maurus). Primates 39: 225-230.

Matsumura S, Watanabe K 1994. Sexual behavior and female reproductive cycles in a wild group of moor macaques (Macaca maurus). In Roeder JJ, Thierry B, Anderson JR, Herrenschmidt N (eds): Current Primatology Vol 2. Université Louis Pasteur, Strasbourg, pp. 33-37.

Mitani JC, Stuht J 1998: The evolution of nonhuman primate loud calls: Acoustic adaptation for long-distance transmission. 
Primates 39: 171-182.

Muroyama Y, Thierry B 1996: Fatal attack on an infant by an adult female Tonkean macaque. Int. J. Primatol. 17:219-227.

Muroyama Y, Thierry B 1998: Species differences of male loud calls and their perception in Sulawesi macaques. Primates 38: 115-125.

Nickelson SA, Lockard JS 1978: Ethogram of Celebes monkeys (Macaca nigra) in two captive habitats. Primates 19: 437-447.

O’Brien TG, Kinnaird MF 1997: Behavior, diet, ánd movements of the Sulawesi crested black macaque (Macaca nigra). Int. J. Primatol. 18: 321-351.

Okamoto K, Matsumura S 1998: A preliminary study on the variables correlated with the emission of loud calls in wild moor macaques (Macaca maurus). Folia Primatol. 69: 277-283.

Palombit RA 1993: A preliminary study of vocal communication in wild long-tailed macaques (Macaca fascicularis). I. Vocal repertoire and call emission. Int. J. Primatol. 13: 143-182.

Petit O, Thierry B 1992: Affiliative function of the silent bared-teeth display in moor macaques (Macaca maurus): Further evidence for the special status of Sulawesi macaques. Int. J. Primatol. 13: 97-105.

Petit O, Thierry B 1994a: Reconciliation in a group of black macaques (Macaca nigra). J. Wild1. Pres. Trusts. 30: 89-95.

Petit O, Thierry B 1994b: Aggressive and peaceful interventions in conflicts in Tonkean macaques. Anim. Behav. 48: 1427-1436.

Petit O, Abegg C, Thierry B 1997: A comparative study of aggression and conciliation in three cercopithecine monkeys (Macaca fuscata, Macaca nigra, Papio papio). Behaviour 134: 415-432.

Preuschoft S 1995: 'Laugther' and 'Smiling' in Macaques. Utrecht, Rijksuniversiteit Utrecht, PhD thesis.

Reed C, O'Brien TG, Kinnaird MF 1997: Male social behavior and dominance hierarchy in the Sulawesi crested black macaque (Macaca nigra). Int. J. Primatol. 18: 247-260.

Smuts BB, Watanabe JM 1990: Social relationships and ritualized greetings in adult male baboons (Papio cynocephalus anubis). Int. J. Primatol. 11: 147-172

Supriatna J, Froelich JW, Erwin JM, Southwick CH 1992: Population, habitat and conservation status of Macaca maurus, Macaca tonkeana and their putative hybrids. Trop. Biodiv. 1: 31-48.

Takenaka O, Hotta M, Kawamoto Y, Suryobroto B, Brotoisworo E 1987: Origin and evolution of the Sulawesi macaques. 2. Complete amino-acid sequences of seven $\beta$ chains of three molecular types. Primates 28: 99-109.

Thierry B, Anderson JR, Demaria C, Desportes C, Petit O 1994: Tonkean macaque behaviour from the perspective of the evolution of Sulawesi macaques. In Roeder JJ, Thierry B, Anderson JR, Herrenschmidt N (eds): Current Primatology Vol 2. Université Louis Pasteur, Strasbourg, pp 103-117.

Thierry B, Demaria C, Preuschoft S, Desportes C 1989: Structural convergence between silent bared-teeth display and relaxed open-mouth display in the Tonkean macaque (Macaca tonkeana). Folia Primatol 52: 178-184.

Thierry B, Gauthier C, Peignot P 1990: Social grooming in Tonkean macaques (Macaca tonkeana). Int. J. Primatol. 11: 357-375.

Thierry B 1986: A comparative study of aggression and response to aggression in three species of macaque. In Else JG, Lee PC (eds): Primate Ontogeny, Cognition and Social Behaviour. Cambridge, Cambridge University Press, pp $307-313$.

Thierry B 1986: Affiliative interference in mounts in a group of Tonkean macaques (Macaca tonkeana). Am J Primatol 14: 89-97.

Thierry B 1984: Clasping behaviour in Macaca tonkeana. Behaviour 89: 1-28.

Thierry B 1985: Patterns of agonistic interactions in three species of macaque (Macaca mulatta, M. fascicularis, M. tonkeana). Aggress. Behav. 11: 223-233.

Thierry B 2000: Covariation of conflict management patterns across macaques. In Aureli F \& de Waal FBM (eds): Natural Conflict Resolution. University of California Press, Berkeley, CA.

Van Hooff JARAM 1967: The facial displays of the catarrhine monkeys and apes. In Morris D (ed): Primate Ethology. Weidenfeld \& Nicolson, London, pp 7-68.

Waser PM, Waser MS 1977: Experimental studies of primate vocalization: Specializations for long-distance propagation. Z. Tierpsychol. 43: 238-263.

Watanabe K, Brotoisworo E 1982: Field observation of Sulawesi macaques. Kyoto Univ Overseas Res Rep Stud Asian Non-human Primates 2: 3-9.

Watanabe K, Matsumura S 1991: The borderlands and possible hybrids between three species of macaques ( $\boldsymbol{M}$. nigra, $\boldsymbol{M}$. nigrescens and $M$. hecki) in the northern peninsula of Sulawesi. Primates 32: 365-369.

Watanabe K, Matsumura S, Watanabe T, Hamada Y 1991: Distribution and possible intergradation between $M a c a c a$ tonkeana and $M$. ochreata at the borderland of the species of Sulawesi. Primates 32: 369-385.

Watanabe K 1979: Some observations of the Mentawai pigtail macaques, Macaca nemestrina pagensis, on Siberut Island, West Sumatra. In Kawamura S (ed): A Comparative Sociological Studies on Coloboid Monkeys in Tropical Asia, Report of Overseas Scientific Survey in 1976-1978. Kyoto University, Inuyama, pp 86-92. 
Watanabe T, Hamada Y, Suryobroto B 1985: Morphological studies of the Sulawesi macaques: somatometry. Kyoto Univ Overseas Res Rep Stud Asian Non-human Primates 4: 79-85.

Whiten AJ, Whiten JE 1982: Preliminary observations of the Mentawai macaques on Siberut Island, Indonesia. Int. J. Primatol. 3: 445-459.

Whitten AL, Mustafa M, Henderson GS 1987: The Ecology of Sulawesi. Gadjah Mada University Press, Yogyakarta.

(要約)

$$
\text { スラウェシマカクの社会行動のレパートリー }
$$

\author{
B. Thierry $^{1)}$, E.L. Bynum ${ }^{2)}$, S. Baker ${ }^{3)}$, M.F. Kinnaird ${ }^{4)}$, S. Matsumura ${ }^{5)}$, \\ Y. Muroyama ${ }^{5)}$, T.G. O'Brien ${ }^{4)}$, O. Petit ${ }^{1)}$, K. Watanabe ${ }^{5)}$ \\ 1) CNRS, Université Louis Pasteur \\ 2) Organization for Tropical Studies \\ 3) James Madison University \\ 4) Wildlife Conservation Society \\ 5）京都大学霊長類研究所
}

野生抢よび飼育下の個体群から集められた資料にもとづいて，スラウェシマカクの社会行動のレパー トリーのエソグラムを作成した。コミュニケーションのパターン, 動きのパターン, 性行動のパターン, 幼児行動と遊び，三者間の社会交渉など社会的文脈で観察されている行動を記述した。これらの行動パ ターンのほとんどはスラウェシマカクの全種に見られた。ある種の行動パターンの形態や機能はほかの マカク種で報告されているあのと著しく異なっていたが，その一方，別の行動パターンに見られた類似 性は, マカク属内の系統的な類縁関係を反映している可能性があった。

\footnotetext{
B. Thierry Laboratoire d'Ethologie des Primates, CNRS-FRE 2130

Université Louis Pasteur, 7 rue de 1'Université, 67000 Strasbourg, France

e-mail: thierry@neurochem.u-strasbg.fr
} 